\title{
CONSERVATION OF AN ACTIVELY CORRODING RARE COPPER-BASED OBJECT FROM THE MUSEUM OF JORDANIAN HERITAGE, JORDAN
}

\author{
Ziad AL SAAD ${ }^{1}$, Abdelrahman ELSEROGY ${ }^{2}$, Sana' AZAIZEH ${ }^{1}$ \\ ${ }^{1}$ Faculty of Archaeology and Anthropology, Yarmouk University-Jordan \\ ${ }^{2}$ Faculty of Archaeology, Fayoum University-Egypt \\ E-mail: ams00@fayoum.edu.eg
}

\begin{abstract}
Copper-based artefacts excavated from high chloride burial environments can develop destructive cyclic corrosion known as the bronze disease when exposed to uncontrolled humidity and oxygen. This research deals with the corrosion behaviour and conservation of a rare Ayyubid Mamluk copper cauldron used for boiling sugar syrup for sugar production in the Jordan Valley. The object was kept in the Museum of Jordanian Heritage storage area for about ten years under uncontrolled and unfavourable climatic conditions. The object developed active corrosion, which threatens its existence. This study aims to preserve the object by implementing proper conservation interventions based on the diagnosis of the corrosion behaviour of the object. Analytical techniques including ICP-OES, X-Ray Diffraction, Optical Microscopy, and Metallographic examinations were used to determine the object chemical composition, manufacturing technology and corrosion behaviour. The object was treated using a multistep conservation process that included mechanical cleaning, treatment with benzotriazole, protective coating and the creation of a controlled microclimate. Its conservation enabled the transfer of the cauldron from being stored to being exhibited.
\end{abstract}

\section{KEYWORDS}

Copper Cauldron, Sugar Production, Jordan Valley, Ayyubid-Mamluk Period, Bronze Disease, Benzotriazole.

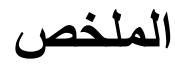

تتعرض القطع الاثرية المصنوعة من معدن النحاس

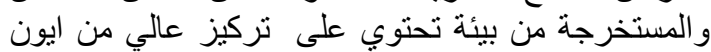

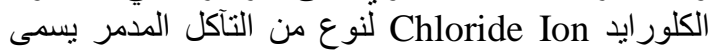

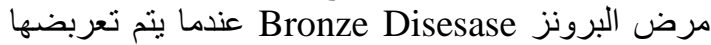

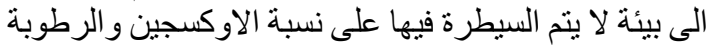

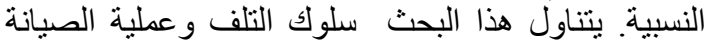
لمرجل نحاسي نادر يعود للفترة الايوبية المملوكية كان

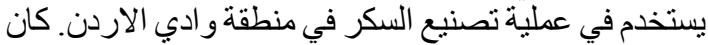

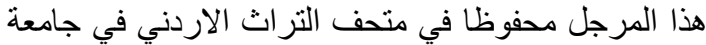
اليرموك لمدة عشر سنو ات في بيئة غير مناسبة لا لا يتم التحكم

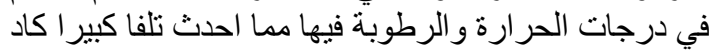

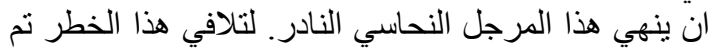

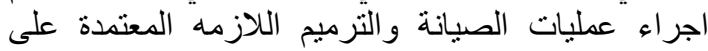
التتخيص العلمى الدقيق لمظاهر ومسبيات التلف ولته والتآكل. تم اجراء عدد من التحاليل العلمية المخبرية بأستخدام تقنية X-Ray Diffraction وحيود الاشعة السينية ICP-OES

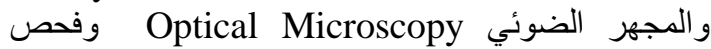
Metallographic Examination التركيب المعدني

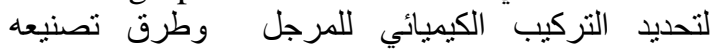
وخصائصه الكيميائية و الفيزيائية والتلف الذئية الذي اصابه. تم اجراء عملية صيانة وترميم متعددة الخطوات التئية للمرجل

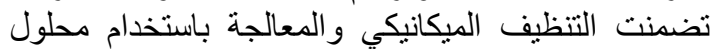

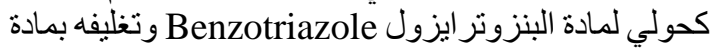

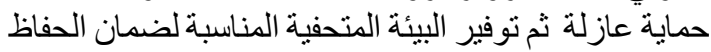

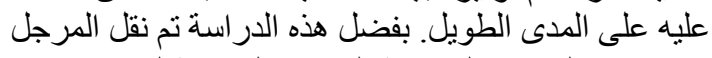
من مخزن المتحف الى قاعة العرض الريل الرئيسية ليصبح واحدا من معروضات المتحف المهمة.
\end{abstract}




\section{INTRODUCTION}

Buried copper-based objects deteriorate during prolonged exposure to harsh burial conditions. The extent and nature of deterioration are governed by factors related to the composition and manufacture of the objects, as well as the characteristics of the burial environment, including texture, $\mathrm{pH}$, soluble salts content, redox potential and organic matter content. ${ }^{1}$ Buried objects may reach equilibrium with their soil environment during long-term burial, especially in stable conditions. Once the state of equilibrium is reached, the rate of corrosion is significantly reduced. However, once excavated and removed from their burial environments, the equilibrium is disturbed. The conditions in which the objects are held change dramatically leading to new cycles of destructive corrosion. These change the mass and composition of corrosion products, causing severe problems to the stability and even existence of the objects. ${ }^{2}$ Copper-based objects excavated from chloride-containing soils can suffer from severe post-excavation corrosion once exposed to new oxygen and relative humidity levels. Such objects usually develop a corrosion layer of cuprous chloride during burial, located at the metal surface under the patina. Upon exposure to damp and oxygenated conditions, cuprous chloride reacts rapidly to form powdery corrosion, disrupting the stable patina and continuing until the object is wholly mineralised. ${ }^{3}$ The bronze disease often begins beneath the existing patina and is not always visually apparent. The appearance of a new corrosion product on the surface shows that active corrosion processes have already progressed to an advanced and damaging level. The destructive effect of the bronze disease is caused by the conversion of cuprous chloride known as Nantokite to basic copper chlorides, usually a mixture of Paratacamite and Atacamite, through exposure to humidity and oxygen. Nantokite is insoluble in water and can remain inactive for an extended period as long as the environmental conditions of the excavated copper objects are controlled, whether in storage or display. When the objects are exposed to moisture and oxygen, Nantokite becomes unstable and reacts to form voluminous corrosion products of basic copper chlorides. It physically disrupts the overlying stable patina layers and forces them apart. The remaining metal core is also attacked by self-perpetuating active corrosion, which can lead to complete mineralisation of the object. ${ }^{4}$

Copper-based objects excavated from Mediterranean sites are most likely to activate corrosion due to the presence of cuprous chloride within their corrosion layers. ${ }^{5}$ Therefore, the monitoring and control of the post-excavation environments (storage or display) of these

\footnotetext{
${ }^{1}$ Nord, A. G., E. Mattsson, and K. Tronner., Factors Influencing the Long-term Corrosion of Bronze Artefacts in Soil, Protection of Metals 41 (4), (2005), 309-316; Podany, J., Corrosion of Metal Artifacts and Works of Art in Museum and Collection Environment. In ASM Handbook Volume 13C, Corrosion: Environments and Industries. ASM International, (2006), 279-288.

2 Selwyn, L.S., Corrosion of metal artifacts in buried environments, ASM handbook. Vol. 13C. Corrosion: Environments and Industries, (2006), 306-322; Scott D.A., Copper and Bronze in Art: Corrosion, Colorants and Conservation. Los Angeles: Getty Conservation Institute Publications, (2002); Nord, A. G., E. Mattsson, and K. Tronner., Factors Influencing the Long-term Corrosion of Bronze Artefacts in Soil, Protection of Metals 41 (4), (2005a): 309-316.

${ }^{3}$ Selwyn, L. S., Recognizing Active Corrosion. CCI Notes 9/1, (Original Text by Logan, J., 1986). www.cciicc. gc.ca/publications/notes/9-1_e.pdf, (Accessed: March 25 2011), (2007); Oudbashi, O., From Excavation to Preservation: Preventive Conservation Approaches in Archaeological Bronze Collections. In La ConservationRestauration des Métaux Archéologiques: des Premiers soins à la Conservation Durable. Ed. S. Clerbois. Institut Du Patrimoine Wallon, (2015), 29-36.

${ }^{4}$ Scott, D. A., Bronze Disease: A Review of Some Chemical Problems and the Role of Relative Humidity, Journal of the American Institute for Conservation, 29(2), (1990), 193-206.

${ }^{5}$ Ingo, G.M., et al., Large scale investigation of chemical composition, structure and corrosion mechanism of bronze archaeological artifacts from Mediterranean basin, App.Phys., A83, Materials science \& processing, (2006), 513-520.
} 
objects are of vital importance. In particular, relative humidity levels and the presence of some pollutants in the museum should be strictly controlled by the museums if chloride contaminated copper-based objects are to remain stable and costly conservation interventions are to be avoided. ${ }^{1}$

This study deals with the condition assessment and conservation of a rare copper-based cauldron that was kept in the storage of the Museum of Jordanian Heritage since it was brought to the museum ten years ago. Despite its lack of information regarding its archaeological context and date, the museum has recently decided to transfer the object from storage to display after the archaeological context, function, and date of the object have been re-established. ${ }^{2}$ The aim of the study was the determination of the extent and cause of deterioration that the object has sustained during its storage. Based on the condition assessment, conservation measures including intervention and preventive measures were implemented to ensure the safeguarding of the object in its new display environment.

\section{MATERIALS AND METHODS}

\section{1- Description of the object}

The object selected is a copper-alloy cauldron from the Museum of Jordanian Heritage at Yarmouk University. Stylistic and scientific analyses show that the object was used for boiling sugar syrup as part of sugar production, which flourished in the Jordan Valley during the Ayyubid-Mamluk period in the $12^{\text {th }}$ century AD. ${ }^{3}$ As shown in Figure 1 , the object has a rounded body, a wide-open mouth, a flaring-out rim and a small disk base. The internal surface is smooth, and the external one is tough. It has six supporting vertical ribs that divide the external surface into six parts. The object weighs about $200 \mathrm{~kg}$, and it measures $100 \mathrm{~cm}$ in diameter, $33 \mathrm{~cm}$ in depth, and $44 \mathrm{~cm}$ tall. This cauldron was encrusted with corrosion products and vivid green spots indicating active corrosion.

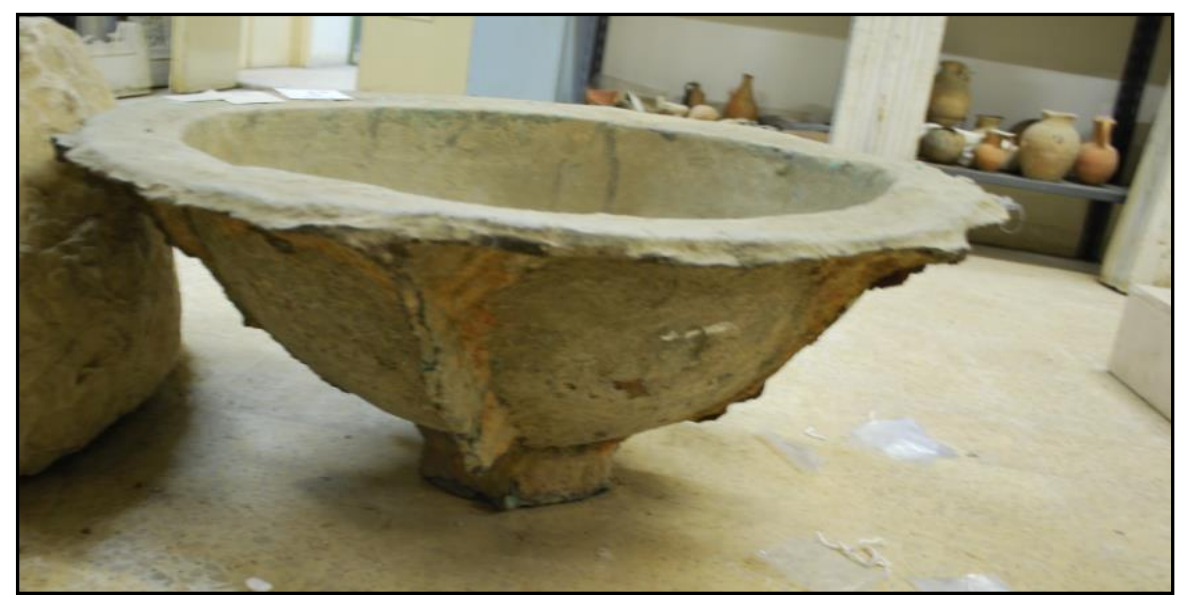

Figure 1: The copper cauldron in the Museum storage area

\footnotetext{
${ }^{1}$ Papapelekanos, A., The Critical RH for the Appearance of "Bronze Disease" in Chloride Contaminated Copper and Copper Alloy Artefacts, E-Conservation Magazine 13, (2010), 43-52.

${ }^{2}$ Ziad Al Saad, Z, and Azaizeh, S., Determination of Provenance and Technology of "Orphaned" Museum Objects: A Case Study from the Museum of Jordanian Heritage, (2020), under review.

${ }^{3}$ Ziad Al Saad, Z, and Azaizeh, S., Determination of Provenance and Technology of "Orphaned" Museum Objects: A Case Study from the Museum of Jordanian Heritage, (2020) under review,
} 


\subsection{Methods and Techniques}

\subsection{1-Characterisation of Corrosion Products}

A combination of different techniques, including visual examination aided with a stereomicroscope, optical microscopy (OM), and X-Ray Diffraction (XRD), was used to identify the morphology, extent, and nature of corrosion products of the object. To study the copper object's morphology, nature and extent of the corrosion, four cross-sections of corrosion fragments were prepared after embedding in epoxy resin for 24 hours, then sectioned using a diamond saw. The cross-sections were polished with silicon carbide papers till 1200 grit, and the final polishing step was performed with diamond pastes up to $1 / 4 \mu \mathrm{m}$ to produce mirror-like surfaces. The morphology and the stratigraphy of the sectioned corrosion layers were acquired by a multi-focus (OM) Leica MZ FLIII microscope. The mineralogical composition of the corrosion products was determined by using X-ray diffraction (600 Shimadzu corporation). The corrosion samples were ground to fine powders in agate mortars. They were then analysed following these operating conditions: X-Ray Generator: $\mathrm{Cu}-\mathrm{K} \alpha$ radiation, Working power: $1.8 \mathrm{kw}$, Working Voltage: $60 \mathrm{kv}$, Working Current: 55mA, Angle Rang: (3-60) $2 \theta$.

\subsection{2-Metallographic Analysis}

Cross-sections were taken from fractured parts of the cauldron using a manual saw to examine its metallographic microstructure and nature of corrosion. Three representative samples from the base, rim and rib were taken to get information about the method of fabrication of the cauldron and its corrosion profile. The cross-sections were prepared by embedding samples in an Araldite 2020 epoxy resin. Preparation for analysis was followed by grinding them with silicon carbide papers (280, 400, 800, 1000, 2000 grit size). Finally, the cross-sections were polished with a diamond paste (beginning at 9-6 $\mu \mathrm{m}$ and reducing to a highly polished surface using $0.25 \mu \mathrm{m}$ ). The embedded cross-section was etched with a ferric chloride alcohol solution (120ml distilled water: $30 \mathrm{ml}$ hydrochloric acid $\mathrm{HCl}$ : $10 \mathrm{~g}$ ferric chloride $\mathrm{FeCl}_{3}$ ). A binocular microscope (ZEISS Stemi 2000-C) was used for the metallographic examination; the photomicrographs were taken using an AxioCamERc 5s camera attachment.

\subsection{3-Chemical Analysis}

The chemical composition of the cauldron was determined using Perkin Elmer OPTIMA 7000DV, Inductively Coupled Plasma Atomic Emission Spectroscopy (ICP-OES). Three different cleaned spots (body, base, and rim) were drilled using a hand-held mini drill with a $1 \mathrm{~mm}$ diameter tungsten carbide bit. The samples were prepared for analysis by the following procedure: $0.20 \mathrm{~g}$ was accurately taken from each sample powder and placed in a holder, and then $2 \mathrm{ml}$ of $48 \mathrm{wt}$. $\% \mathrm{HF}, 8 \mathrm{ml}$ of $65 \mathrm{wt} . \% \mathrm{HNO}_{3}$ and $2 \mathrm{ml}$ of $30 \mathrm{wt} \% \mathrm{H}_{2} \mathrm{O}_{2}$ were added. The samples were digested using Milestone ETHOS1, a microwave digestion system. The samples were then transferred volumetrically to a $50 \mathrm{ml}$ centrifuge test tube at room temperature. $4 \%$ boric acid (to remove the HF effect) was added to the samples. The samples were then diluted with $1 \%$ sub boiled Nitric Acid $\left(\mathrm{HNO}_{3} 65 \%\right) 10$ times as a dilution factor, so the last dilution volume was $500 \mathrm{ml}$.

\subsection{4-Conservation Treatment}

The object was mechanically cleaned from encrustations and powdery corrosion products. Careful mechanical cleaning was done using abrasive tools, such as scalpels, scrapers, dental picks of different sizes and soft bristle brushes. In this operation, the tools were used parallel to the surface to avoid scratching the original surface. Hard encrustations were softened by a 
localised application of $10 \%$ solution of Ethylene Diamine Tetra-acetic Acid (EDTA). Chemical treatment was followed by thorough rinsing with running deionised water and then dried by ethanol. The object was treated with a $3 \%$ ethanol solution of Benzotriazole (BTA) by brushing it several times with the solution to ensure that it was covered. The object was wiped off with a rag saturated in ethanol to remove excess BTA. The object was then exposed to an uncontrolled high humidity environment for 3 months to observe the development of any bronze disease trace. After that, the object was finally coated with three layers of $5 \%$ acetone solution of Paraloid B-72.

\section{RESULTS AND DISCUSSION}

\section{1-Charcterisation of Nature and Extent of Corrosion}

Microscopic investigation showed that the object developed thick-layered corrosion products. The object has a relatively stable patina of green malachite covered with a white carbonate layer overlaying a mixed red-black oxide layer in contact with the metalcore. Eruptions of light green powdery patches through the overlying patina were detected on different areas of the objects, as shown in Figure 2. The voluminous and lustrous deposits are signs of active severe corrosion.
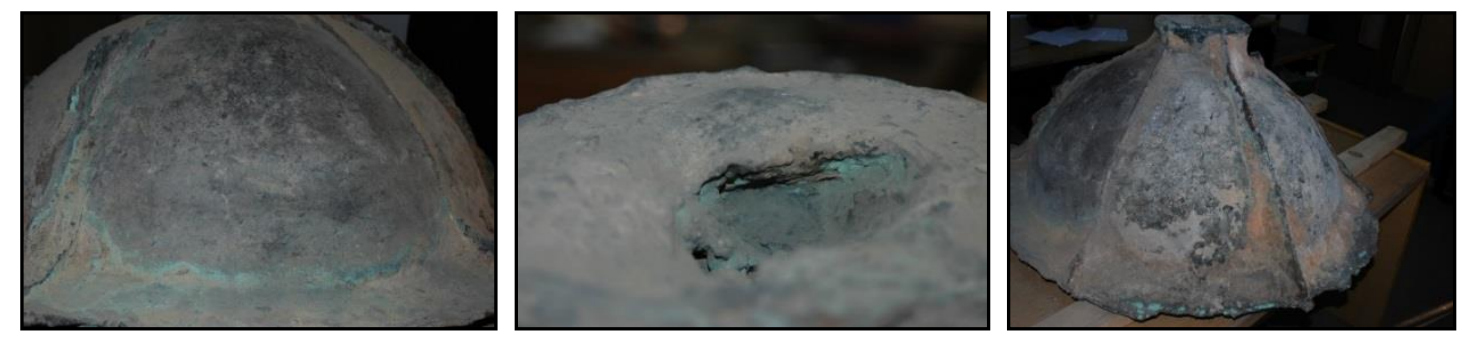

Figure 2. Active corrosion manifested by green lustrous spots and eruptions.

Optical microscopy examination of thin sections disclosed that the object had developed stratified corrosion layers as shown in Figure 3: a pale green layer directly related to $\mathrm{Cu}$ (II) compounds (carbonates and/or copper-oxychlorides); white patches of cuprous chloride (nantokite, $\mathrm{CuCl}$ ) at the interface between external corrosion products and metal alloy relics and along the grain boundaries; layered aggregates of cuprite $\left(\mathrm{Cu}_{2} \mathrm{O}\right)$, and grey-black layer of cupric oxide (tenorite, $\mathrm{CuO}$ ).

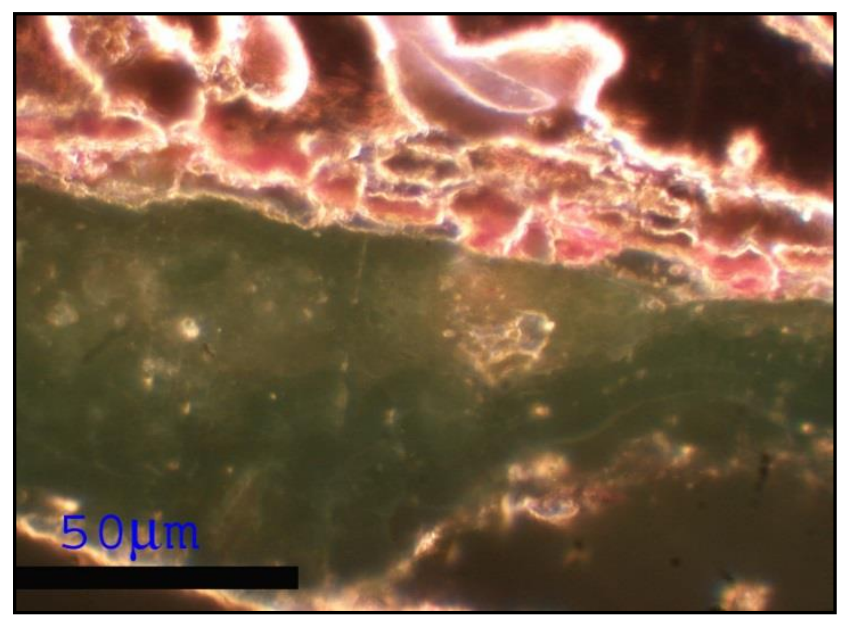

Figure 3. Optical microscopy microphotograph showing the stratified corrosion of the object. 
Table 1. Identified corrosion compounds by XRD analysis

\begin{tabular}{ccc}
\hline Sample no /name & Corrosion products & Formula \\
\hline 1: Red & $\begin{array}{c}\text { Cuprite } \\
\text { Paratacamite }\end{array}$ & $\begin{array}{c}\mathrm{Cu}_{2} \mathrm{O} \\
\left(\mathrm{CuCl}_{2} .3 \mathrm{Cu}(\mathrm{OH})_{2}\right)\end{array}$ \\
2: Black & Tenorite & $(\mathrm{CuO})$ \\
& Malachite & $\left(\mathrm{Cu}_{2} \mathrm{Co}_{3}(\mathrm{OH})_{2}\right.$ \\
3: Green & Paratacamite & $\left(\mathrm{CuCl}_{2} .3 \mathrm{Cu}(\mathrm{OH})_{2}\right)$ \\
& Calcite & $\left(\mathrm{CaCO}_{3}\right)$ \\
& Calcite & $\left(\mathrm{CaCO}_{3}\right)$ \\
& Gypsum & $\left(\mathrm{CaSO}_{4} .2 \mathrm{H}_{2} \mathrm{O}\right)$ \\
& Quartz & $\left(\mathrm{SiO}_{2}\right)$ \\
& Paratacamite & $\left(\mathrm{CuCl}_{2} .3 \mathrm{Cu}_{2}(\mathrm{OH})_{2}\right)$ \\
\hline
\end{tabular}
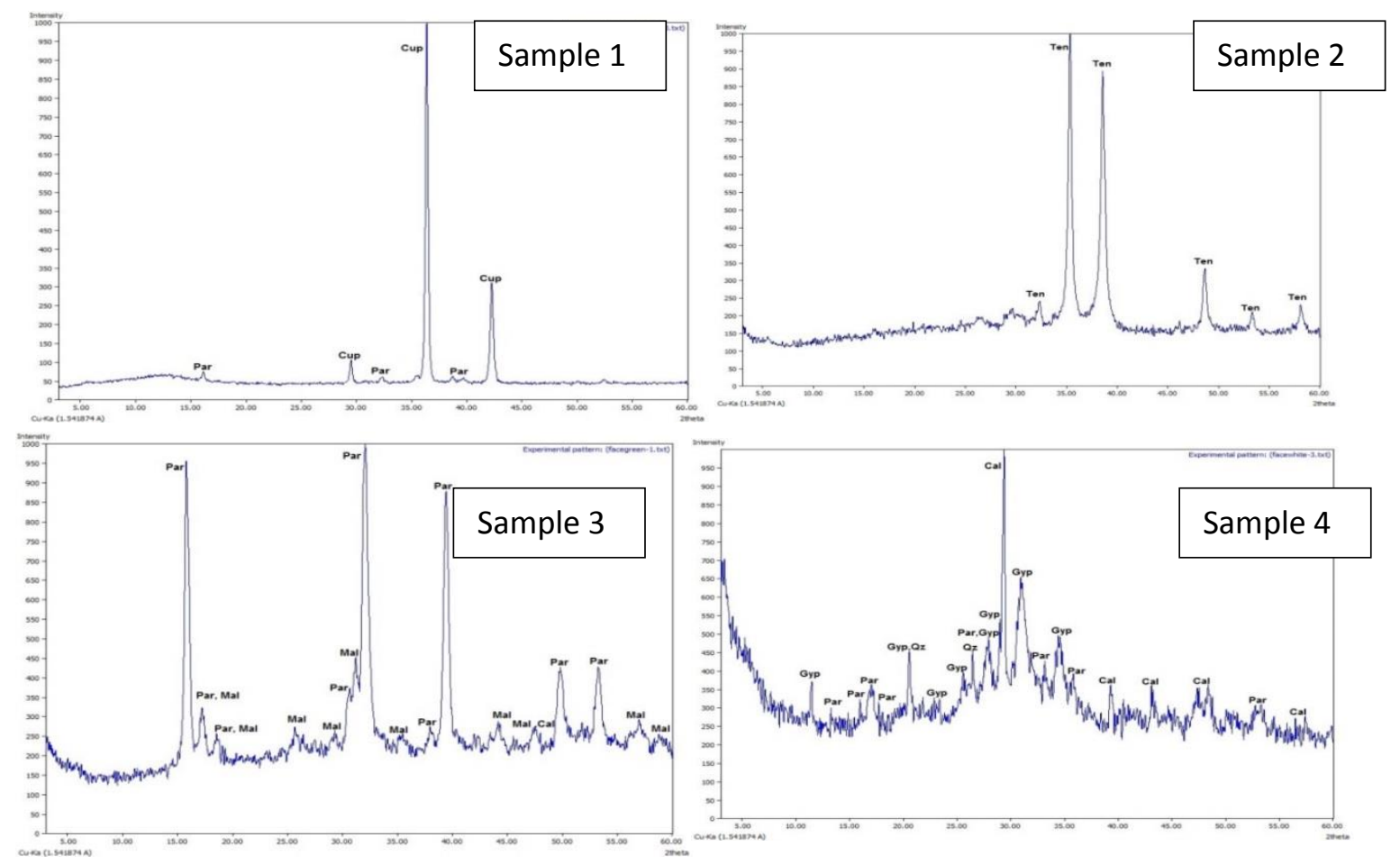

Figure 4. XRD Diffractograms of the four corrosion samples

Cuprite and malachite are commonly reported corrosion products on archaeological copper alloys. ${ }^{1}$ Cuprite preserves detail of the original surface of the object. It acts as a marker layer, which is indicative of the initial corrosion interface between the metal core and the environment. A dark grey/black corrosion product was identified as tenorite $(\mathrm{CuO})$. The

\footnotetext{
${ }^{1}$ Scott, D., 'Copper Compounds in Metals and Colorants: Oxides and Hydroxides', in: Studies in Conservation. 42, (1997), 93-100; Scott, D. Copper and Bronze in Art Corrosion, colorants, conservation. Getty Conservation Institute, Los Angeles, (2002); Selwyn, L., Metals and Corrosion A Handbook for the Conservation Professional. Minister of Public Work and Government Services, Canada, 2004.
} 
presence of tenorite as a corrosion product indicates that the artefact has been subjected to heating before or during its burial. ${ }^{1}$ Tenorite has also been found as an alteration product of cuprite forming a thin dark layer over the red. ${ }^{2}$ In the basic environment of a burial site, tenorite results in an alteration product of azurite or decomposition of copper (I) chloride (cuprous chloride) under very alkaline conditions. ${ }^{3}$ Regarding the preservation of copper objects, copper carbonates and oxides are relatively stable corrosion layers but do not preserve the surface details of the object. Nevertheless, they can help slow the progression of further corrosion. The major long term stability concern is detecting the abundance or nearly constant presence of Paratacamite $\left(\mathrm{CuCl}_{2} .3 \mathrm{Cu}(\mathrm{OH})_{2}\right)$ inside the corrosion layers. Its presence is a strong indication of ongoing destructive active corrosion, customarily called the bronze disease. Chloride ions usually enter in the electrochemical corrosion process of copper during burial in chloride-containing soils. Chlorides are the most aggressive anions for the corrosion of copper-based objects. Chloride ions migrate towards the metal surface and react with copper ions leading to nantokite $(\mathrm{CuCl})$ forming underneath the copper oxides and carbonates. Nantokite remains stable in the absence of oxygen and water. ${ }^{4}$ The bronze disease appears when nantokite is exposed to oxygen and moisture upon excavating buried objects. When water reacts with nantokite, hydrated copper chlorides are formed, including atacamite, paratacamite and botallackite, accompanied by a release of chloride ions. The conversion of nantokite into hydrated copper chloride is very destructive due to two factors: the much higher volume of the formed hydrated copper chlorides compared to nantokite, which causes destructive eruptions through the overlying patina and embrittlement of the object, and nantokite conversion reaction, which is accompanied by the regeneration of chloride ions that attack fresh copper. This cyclic process may continue until the original metal of the artefact is gone, leaving only a heap of blue dust. ${ }^{5}$ The cauldron originated from Al-Kraima site in the Jordan Valley with no information on its handling and storage conditions before it was brought to the museum. Based on primary measurements, the soils of the site are characterised by high chloride content. The museum kept the object for around ten years in its storage, with no control of the surrounding environment. There, the RH of the museum varies from 40 to $70 \%$ during the year. Although it is difficult to know when the active corrosion of the object started, a copper-based object contaminated with chlorides and exposed to oxygen and abundant moisture would inevitably suffer from active corrosion. The improper storage conditions have caused several cycles of active corrosion, as indicated by the object embrittlement and powdery eruptions on its surface.

\section{2- Chemical Composition}

The chemical composition results presented in Table 2 show that the cauldron was made of

\footnotetext{
${ }^{1}$ Scott, D.A., Copper and Bronze in Art: Corrosion, Colorants and Conservation. Los Angeles: Getty Conservation Institute Publications, (2002).

${ }^{2}$ Scott, D. 'Copper Compounds in Metals and Colorants: Oxides and Hydroxides', in: Studies in Conservation. 42, (1997), 93-100.

${ }^{3}$ Gutscher, D\& Muhlethaler, B\& Portmann, A\& Reller, A., Conversion of Azurite into Tenorite, in: Studies in Conservation. 34, (1989), 117-122.

${ }^{4}$ Scott, D. A., Bronze Disease: A Review of Some Chemical Problems and the Role of Relative Humidity, Journal of the American Institute for Conservation, 29(2), (1990), 193-206; Macleod, I.. Bronze Disease: An Electrochemical Explanation. Bulletin Institute For The Conservation Of Cultural Material (INC) Volume VII (1) $1981,16-26$.

${ }^{5}$ Scott, D. A., Bronze Disease: A Review of Some Chemical Problems and the Role of Relative Humidity, Journal of the American Institute for Conservation, 29(2), (1990), 193-206; Macleod, I.. Bronze Disease: An Electrochemical Explanation. Bulletin Institute For The Conservation Of Cultural Material (INC) Volume VII (1), 1981, 16-26; Robbiola, L\& Blengino, J. M. \& Fiaud, C., Morphology and Mechanisms of Formation of Natural Patinas on Archaeological Cu-Sn Alloys. Corrosion Science 40 (12), 1998, 2083-211.
} 
copper (average $\mathrm{Cu}$ of $93.6 \%$ ) with low lead content (average $\mathrm{Pb}$ of $2.9 \%$ ) and almost no content of the common alloying elements of copper, tin and zinc. The lead was most probably intentionally added to the molten copper to make the casting easier. Such proportion of lead is enough to enhance the fluidity of the molten alloy, an important property to facilitate the manufacturing process of the cauldron. ${ }^{1}$ Although pure copper is less resistant to corrosion than bronze or brass, the chemical composition is not a decisive factor in the corrosion behaviour of the cauldron when compared to other factors like the burial soil chemistry and storage conditions of the object.

Table 2: Chemical analysis results in wt.\% as measured by ICP-OES.

\begin{tabular}{llllllllll}
\hline Sampls & $\mathrm{Cu}$ & $\mathrm{Pb}$ & $\mathrm{Sn}$ & $\mathrm{Fe}$ & $\mathrm{Sb}$ & $\mathrm{As}$ & $\mathrm{Co}$ & $\mathrm{Ni}$ & $\mathrm{P}$ \\
\hline 1. Rib & 94.105 & 2.622 & $*_{-}$ & 0.018 & 0.358 & 0.376 & 0.005 & 0.049 & 1.589 \\
2. Base & 94.251 & 2.446 & $*_{-}$ & 0.029 & 0.3199 & 0.313 & 0.005 & 0.049 & 1.536 \\
3. Body & 92.505 & 3.808 & 0.349 & 0.059 & 0.300 & 0.301 & 0.005 & 0.051 & 1.643 \\
\hline
\end{tabular}

*: under detection limit

\section{3-Metallographic Analysis}

The microstructure investigation showed that the microstructure of the cauldron is composed of alpha deformed copper dendrites with lead globules in the boundaries indicating that the object was produced by casting followed by thermal and mechanical working (Figure 5). Different size and unequal axes recrystallised grain or slip lines indicate that the repeated cycles of mechanical working and thermal treatments were carried out during the manufacturing of the object. Slip bands suggest that the object was overworked, and the annealing process was not sufficient to remove the stress within all the grains. The deformation of metal grains caused by the manufacturing process harms the corrosion resistance of the object. ${ }^{2}$

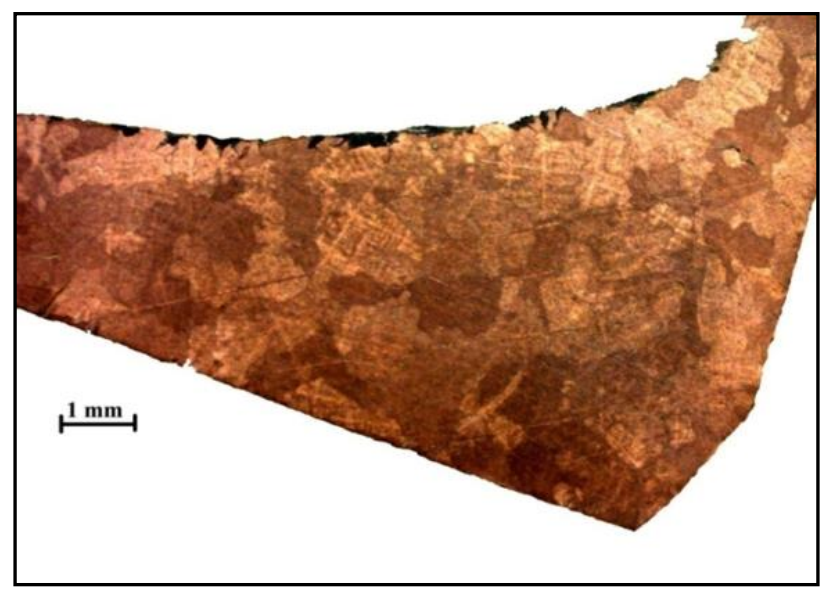

Figure (5) Photomicrograph showing deformed dendrites, twins and strain lines.

Strained and deformed metal grains can cause intergranular corrosion and cracks, as shown in Figure 6.

\footnotetext{
${ }^{1}$ Giumlia-Mair, A\& Keall, E. J\& Shugar, A. N\&Stock, S., Investigation of a Copper-based Hoard from the Megalithic Site of al-Midamman, Yemen: an Interdisciplinary Approach, Journal of Archaeological Science. 29, (2002), 195-209. Craddock, P. T., The Copper Alloys of the Medieval Islamic world-inheritors of the Classical Tradition, World Archaeol .11(1), (1979), 68-79.

${ }^{2}$ Scott, D., Metallography and Microstructure of Ancient and Historic Metals. The Getty Conservation Institute, The J. Paul Getty Museum,1991.
} 


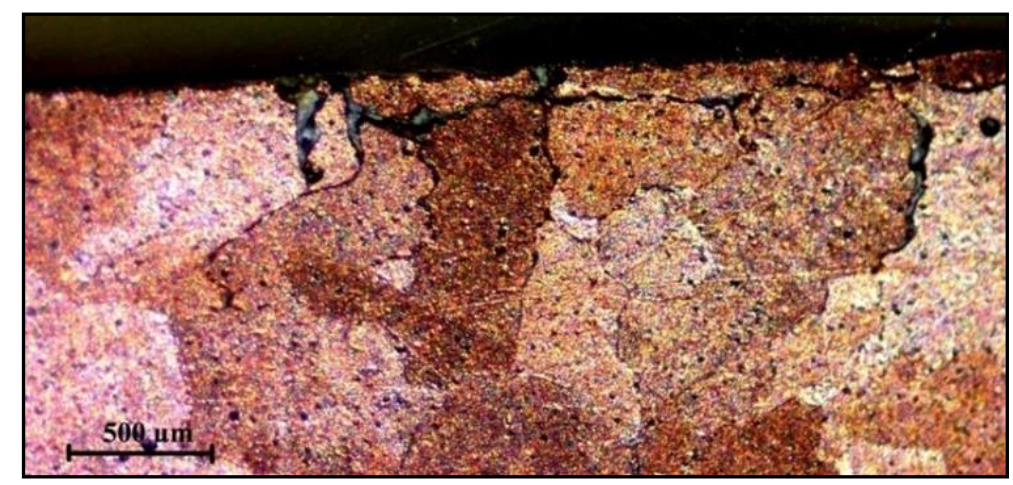

Figure (6) A General View of the Cauldron Cross-Section With Clear Intergranular Cracks and

\section{4- Conservation Treatment}

Corrosion

Conservation intervention was essential as a prerequisite for transferring the object from storage to display. The conservation intervention's main aim was to reveal the original shape of the object, preserve its aesthetic and historical values necessary for its presentation in the museum display, and assure its long-term stability. These aims were achieved by adopting a minimum intervention approach that could reveal the object's original shape, preserve its stable patina and disrupt the active conservation cycles ${ }^{1}$. The conservation treatment comprised a combination of measures, including removing outer encrustations and disfigured eruptions, sealing the object from oxygen and moisture and controlling its exhibition environment. The outer encrustation and loose corrosion products were cleaned to reveal the preserved surface of the cauldron by using a combination of mechanical and localized chemical cleaning methods. Mechanical cleaning was done with great care by using abrasive tools (scalpels, scrapers, dental picks of different sizes and soft bristle brushes). The chemical cleaning was only used to soften hard encrustation that is difficult to be removed by mechanical cleaning only without scratching the original surface of the object. EDTA was locally used to convert insoluble encrustation into soluble that can be washed away easily with water. Figures 6 and 7 show the object before and after cleaning.
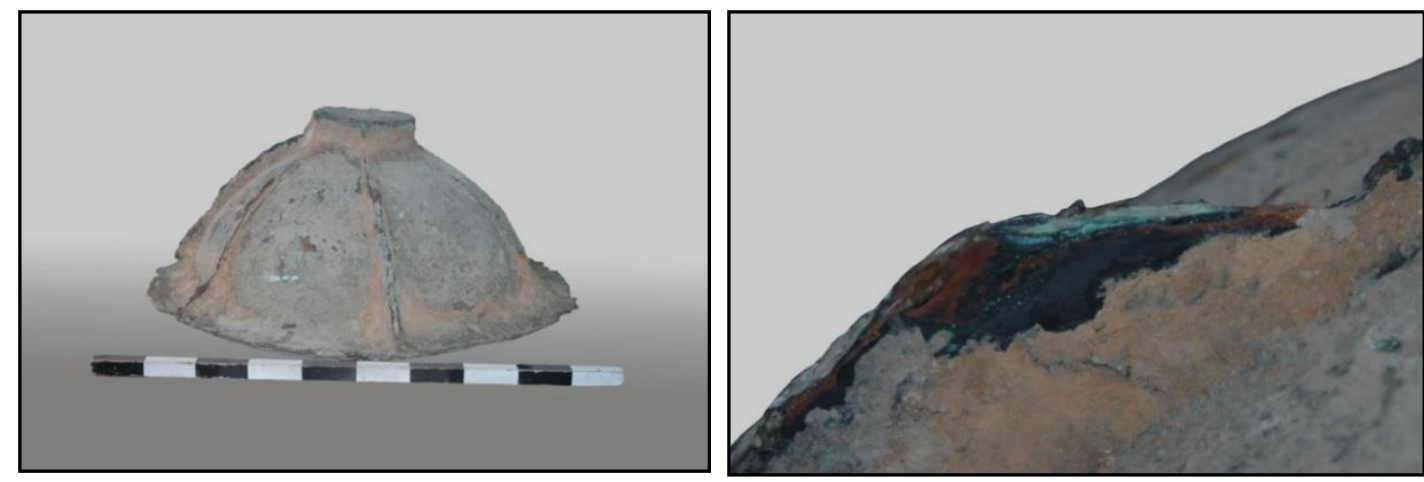

Figure (6) Object before cleaning

\footnotetext{
${ }^{1}$ Caple, C., Conservation Skills: Judgment, Method and Decision Making, Routledge, New York, 1st Edition, (2000), 65 .
} 

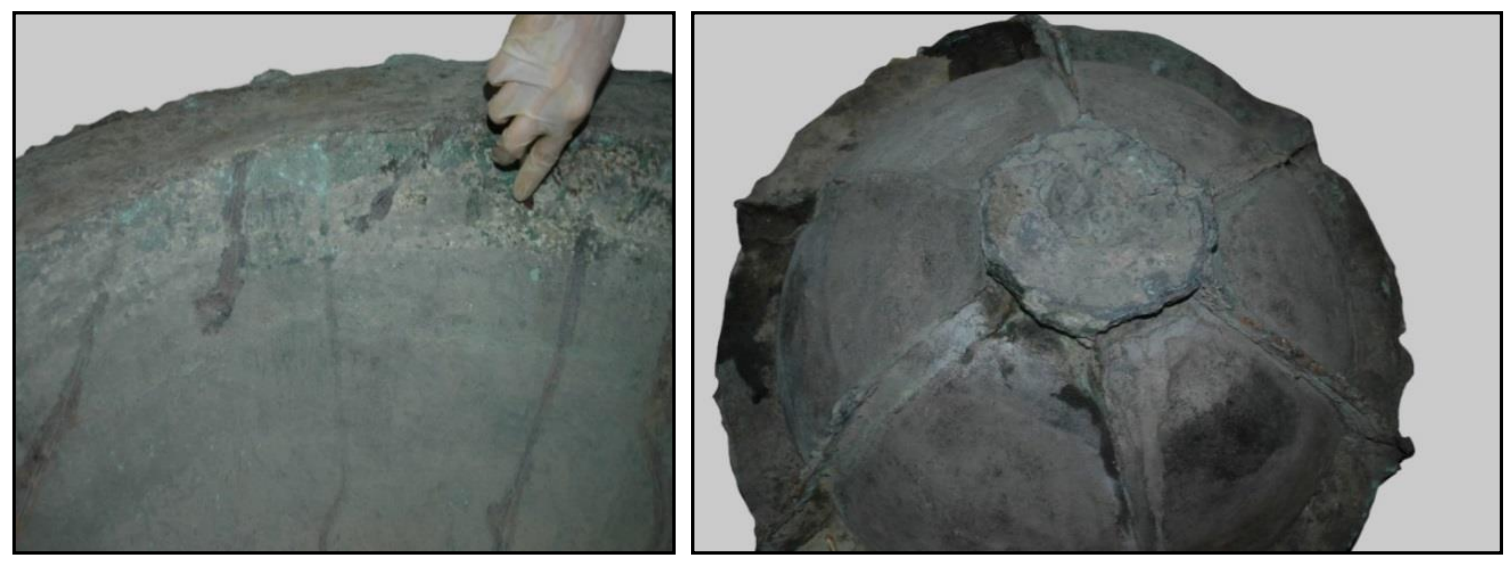

Figure (7) Object after cleaning

\section{Sealing the object from atmosphere}

The key to the preservation of copper-based objects suffering from the bronze disease is the prevention of the adverse chemical action of chloride. Three approaches can be used to achieve this goal. ${ }^{1}$ The first approach is based on removing the cuprous chloride; the second approach converts the cuprous chloride to harmless cuprous oxide. The third approach is based on sealing the cuprous chloride in the object from the surrounding environment. Removing cuprous chloride can be achieved either by galvanic cleaning, electrolytic reduction or by treatment with alkaline dithionite. While these treatments can remove cuprous chloride from the object, they can indiscriminately strip the corrosion layers of the object leading to loss of archaeological information and harm the object's aesthetic value. Converting cuprous chloride into harmless copper oxide can be achieved by treatment with sodium sesquicarbonate or sodium carbonate. The major drawbacks of these treatments are the undesirable change in the colour of the patina, formation of black spots on the surface and the extended treatment periods required, which may reach years, especially for large objects like the object of this study. ${ }^{2}$ The third approach is based on sealing cuprous chloride from moisture to prevent cyclic bronze disease reactions used to treat the cauldron. Although this method is not ideal, it remains the best available treatment so far. Treatment with benzotriazole does not remove the cuprous chloride from the object; instead, it forms a barrier between the cuprous chloride and moisture of the atmosphere by forming an insoluble, complex compound with cupric ions. Impregnating the object with a 3\% ethanol solution of benzotriazole was done to ensure that the solution penetrated all cracks and crevices of the object. The major concern in this treatment is handling the solution to avoid contact with skin

\footnotetext{
${ }^{1}$ Uminski, M., \& Guidetti, V., The Removal of Chloride Ions From Artificially Corroded Bronze Plates, Studies in Conservation, 40(4), (1995): 274-278; Argyropoulos, V., Mavroforaki, S., Giannoulaki, M., Boyatzis, S., Karabotsos, T., Zacharopoulou, A., and Guilminot, E., New Approaches in Stabilizing Chloride-Contaminated Ancient Bronzes Using Corrosion Inhibitors and/or Electrochemical Methods to Preserve Information in the Patinas, Proceedings of XIXth International Congress on Ancient Bronzes @ Artistry in Bronze the Greeks and Their Legacy", Getty Institute for Conservation, USA., (2015).

${ }^{2}$ MacLeod, I.,. Conservation of Corroded Copper Alloys: A Comparison of New and Traditional Methods for Removing Chloride Ions, Studies in Conservation, Vol. 32, No. 1, 1987, 25-40; Georgia, L. F., A Note on the Use of Alkaline Dithionite for Treating Ancient Bronze Artifacts, Studies in Conservation, Vol. 40, No., (1995): 139-142 (18) (PDF) A Note on the Use of Alkaline Dithionite for Treating Ancient Bronze Artifacts. Available from:https://www.researchgate.net/publication/271950216_A_Note_on_the_Use_of_Alkaline_Dithionite_for _Treating_Ancient_Bronze_Artifacts [accessed Jun 05 2020].
} 
or inhalation as BTA is a suspected carcinogen. ${ }^{1}$ For extra protection of the object from atmospheric humidity and corrosive ions, it was coated with a 5\% acetone solution of Paraloid B-72, chosen for ease of application, durability, reversibility and availability.

\section{5- Control of exhibition environment}

In order to ensure the long-term stability of the object during its display in the museum, the object has to be displayed under controlled environmental conditions. The museum has been informed to provide an airtight and dustproof showcase with a controlled microclimate of a constant temperature of $22 \mathrm{C}^{\circ}$ and a fixed relative humidity of $40 \%$. The cauldron is now displayed at the museum main exhibition hall, as shown in Figure 8.

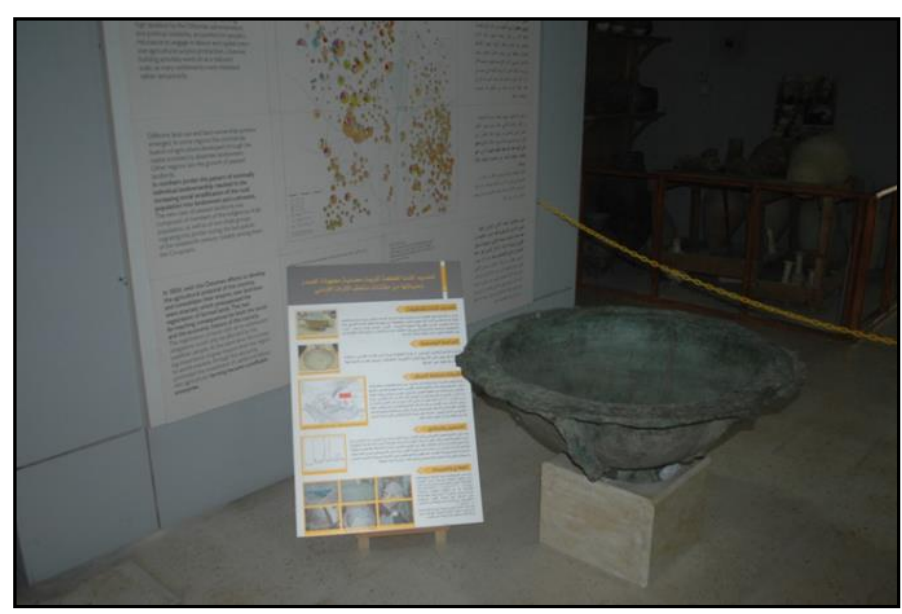

Figure (8) The cauldron as exhibited in the main hall of the Museum of Jordanian Heritage.

\section{CONCLUSION}

The results of this study show clearly that the primary cause of deterioration of copper-based objects and negatively affect their long-term stability is the ubiquitous chloride ions inside the corrosion layers that induce destructive cyclic corrosion. Chlorides containing copper objects remain relatively stable until the reactive cuprous chloride $(\mathrm{CuCl})$ is located at the interface between external corrosion products. The surviving core metal is exposed to uncontrolled levels of humidity and oxygen, which usually occurs due to the improper handling and storage post-excavation. Museums treating this kind of object with carelessness triggers active corrosion cycles that may not stop until the objects are mineralised. Therefore, the key to the long-term stability of copper objects, especially those containing chlorides, is the strict control of their surrounding environments, particularly relative humidity. These objects should be kept under a constant RH level below 40\%. Copper-based objects suffering from active bronze disease corrosion should be immediately subjected to conservation treatment to stop the destructive action of such corrosion. Eliminating oxygen and humidity in museum environments is technically impractical. The best approach for conservation treatment of copper objects suffering from the bronze disease is isolating the infected objects from surrounding environments by treatment with benzotriazole. This corrosion inhibitor forms a protective film on the object surface. Although there have been many scientific studies on the application of corrosion inhibitors to bronze heritage conservation,

\footnotetext{
${ }^{1}$ Sease, C., Benzotriazole: A Review for Conservators, Studies in Conservation, Vol. 23, No. 2 n (1978): 7685; Cao, P. G., Yao, J. L, Zheng, J. W. Gu, R. A. and Tian, Z. Q. 2002. Comparative Study of Inhibition Effects of Benzotriazole for Metals in Neutral Solutions As Observed with Surface-Enhanced Raman Spectroscopy, Langmuir 18 (1), 100-104.
} 
Benzotriazole treatment remains the most widely used and accepted method by conservators. However, benzotriazole's long-term efficacy and toxicity should always be taken seriously to find a more effective and safer alternative. 


\section{BIBLIOGRAPHY}

1-Nord, A. G\& Mattsson, E\& Tronner, K., 'Factors Influencing the Long-term Corrosion of Bronze Artefacts in Soil', Protection of Metals 41 (4), 2005, 309-316.

2- Podany, J., 'Corrosion of Metal Artifacts and Works of Art in Museum and Collection Environment', In ASM Handbook Volume 13C, Corrosion: Environments and Industries. ASM International, 2006, 279-288.

3- Selwyn, L.S., Corrosion of metal artifacts in buried environments, ASM handbook. Vol. 13C, Corrosion: Environments and Industries, 2006, 306-322.

4-Scott, D.A., Copper and Bronze in Art: Corrosion, Colorants and Conservation, Los Angeles: Getty Conservation Institute Publications, 2002.

5- Nord, A. G\& Mattsson E.\& Tronner, K., 'Factors Influencing the Long-term Corrosion of Bronze Artefacts in Soil', Protection of Metals 41 (4), 2005, 309-316.

6- Selwyn, L. S. 2007. Recognizing Active Corrosion. CCI Notes 9/1, (Original Text by Logan, J., 1986). www.cci-icc.gc.ca/publications/notes/9-1_e.pdf (Accessed: March 25 2011).

7-Oudbashi, O., 'From Excavation to Preservation: Preventive Conservation Approaches in Archaeological Bronze Collections', In La Conservation-Restauration des Métaux Archéologiques: des Premiers soins à la Conservation Durable. Ed. S. Clerbois. Institut Du Patrimoine Wallon, 2015, 29-36.

8-Scott, D. A., 'Bronze Disease: A Review of Some Chemical Problems and the Role of Relative Humidity', Journal of the American Institute for Conservation, 29(2), 1990, 193 206.

9-Ingo, G.M., et al., Large scale investigation of chemical composition, structure and corrosion mechanism of bronze archaeological artifacts from Mediterranean basin, App.Phys., A83, Materials science \& processing, 2006, 513-520.

10- Papapelekanos, A.. 'The Critical RH for the Appearance of "Bronze Disease" in Chloride Contaminated Copper and Copper Alloy Artefacts', E-Conservation Magazine 13, 2010, 4352.

11- Ziad Al Saad, Z\& Azaizeh, S., Determination of Provenance and Technology of "Orphaned" Museum Objects: A Case Study from the Museum of Jordanian Heritage, Under review, Mediterranean Archaeology and Archaeometry, 2020.

12-Scott, D., 'Copper Compounds in Metals and Colorants: Oxides and Hydroxides', Studies in Conservation. 42, 1997, 93-100.

13-Scott, D., Copper and Bronze in Art Corrosion, colorants, conservation. Getty Conservation Institute, Los Angeles, 2002.

14-Selwyn, L., Metals and Corrosion A Handbook for the Conservation Professional. Minister of Public Work and Government Services, Canada, 2004.

15- Gutscher, D\& Muhlethaler, B\& Portmann, A\& Reller, A., Conversion of Azurite into Tenorite, Studies in Conservation. 34, 1989, 117-122.

16- Macleod, I., Bronze Disease: An Electrochemical Explanation, Bulletin Institute For The Conservation Of Cultural Material (INC) Volume VII (1), 1981.

17- Robbiola, L\& Blengino J. M. \& Fiaud C., 'Morphology and Mechanisms of Formation of Natural Patinas on Archaeological Cu-Sn Alloys',Corrosion Science 40 (12), 1998, 20832111.

18- Giumlia-Mair, A\& Keall, E. J\& Shugar, A. N\& Stock, S., 'Investigation of a Copperbased Hoard from the Megalithic Site of al-Midamman, Yemen: an Interdisciplinary Approach', Journal of Archaeological Science. 29, 2002,195-209.

19- Craddock,P. T., The Copper Alloys of the Medieval Islamic world-inheritors of the Classical Tradition, World Archaeol .11(1), 1979, 68-79. 
20- Scott, D., Metallography and Microstructure of Ancient and Historic Metals. The Getty Conservation Institute, The J. Paul Getty Museum, 1991.

21-Caple, C., Conservation Skills: Judgment, Method and Decision Making, Routledge, NewYork, 1st Edition. 2000.

22-Uminski, M\& Guidetti, V.,'The Removal of Chloride Ions From Arificially Corroded Bronze Plates', Studies in Conservation, 40(4), 1995, 274-278.

23- Argyropoulos, V\& Mavroforaki, S\& Giannoulaki, M\& Boyatzis, S\& Karabotsos, T\& Zacharopoulou, A\& Guilminot, E., 'New Approaches in Stabilizing Chloride-Contaminated Ancient Bronzes Using Corrosion Inhibitors and/or Electrochemical Methods to Preserve Information in the Patinas', Proceedings of XIXth International Congress on Ancient Bronzes Artistry in Bronze the Greeks and Their Legacy", Getty Institute for Conservation, USA, 2015.

24- MacLeod, I., 'Conservation of Corroded Copper Alloys: A Comparison of New and Traditional Methods for Removing Chloride Ions', Studies in Conservation Vol. 32, No. 1, 1987, 25-40.

25- Georgia L. F., 'A Note on the Use of Alkaline Dithionite for Treating Ancient Bronze Artifacts', Studies in Conservation, Vol. 40, No. 1995, 139-142 (18) (PDF) A Note on the Use of Alkaline Dithionite for Treating Ancient Bronze Artifacts. Availablefrom: https://www.researchgate.net/publication/271950216_A_Note_on_the_Use_of_Alkaline_D ithionite_for_Treating_Ancient_Bronze_Artifacts [accessed Jun 05 2020].

26- Sease, C., 'Benzotriazole: A Review for Conservators', Studies in Conservation, Vol. 23, No. 2, 1978, 76-85.

27- Cao, P. G\& Yao, J. L\& Zheng, J. W\& Gu, R. A. \& Tian, Z. Q., 'Comparative Study of Inhibition Effects of Benzotriazole for Metals in Neutral Solutions As Observed with Surface-Enhanced Raman Spectroscopy', Langmuir 18 (1), 2002, 100-104. 